UDC 81'42:327.82

DOI https://doi.org/10.32838/2710-4656/2021.2-1/20

Holtseva M. I.

Borys Grinchenko Kyiv University

\title{
PRAGMATICS OF DECEPTION IN THE UN SECURITY COUNCIL: HIERARCHY OF PRAGMATIC ATTITUDES
}

The article focuses on deceptive utterances in diplomatic discourse. As diplomats represent their countries on the world stage, sometimes they may present the information in the most favorable light for them. In other words, they deceive. The purpose of deception is to mislead, conceal a fact, to persuade an opponent. Special attention is paid to verbalization of deception and the ways of implementing it through the signs of deception. This paper provides a detailed account of the hierarchy of pragmatic attitudes of deception in the communicative situation of the UN Security Council meetings.

Pragmatics deals not only with the background information, but also with the conditions of a speaker to use a proper sign. The structure of a language sign is interpreted via the formal 7-level systemic model. Together with the structure of deception and its verbal realization during the diplomatic meetings, starting from the reason of the meeting, and ending with the final result. Thus, a three-dimensional sign space has been used, which is realized at semantic, syntactic and pragmatic levels. As a result, we have illustrated how exactly these levels are realized in the diplomatic discourse. We have concentrated our attention on a specific litigation between the representatives of America and Russia.

This paper holds that the information distortion is not a personal issue, being involved in the military and business connections between different countries, thus appearing to a collective issue. As a result of these connections, three groups of interests are determined: 1) CSTO and SCO; 2) NATO and EU; 3) the League of Arab States. The first two groups of alliances are the main opponents who tend to deceive in most cases. The last group is usually a victim side, where the former two argue and deceive blaming each other for being economical with the truth.

Key words: speech act, linguistic expression of deception, pragmatic attitudes, sign, pragmatics.

Introduction. Pragmatics as a branch of theoretical studies has always had a powerful background of various disciplines such as logics, philosophy, semiotics, linguistics among others. We have decided to concentrate on pragmatics due to the background information and the aim of deception, which is our special scholarly interest. Nowadays it is axiomatic that any utterance seeks to influence the recipient and affect the reality. Induced diplomatic discourse (hereinafter DD) is very much implicit by nature in the way the said and unsaid correlate to influence diplomats. In this research we show the hierarchy of pragmatic aspects of deception. As widely known among linguists, a typical speech act consists of the following trio, which is the locution, illocution perlocution acts [22, p. 1]. According to the classification of the speech act theory, every message goes through the process of creating an idea, a thought, then moves to the verbal form of this idea, ending with its final aim, which in case of deceiving is hidden by the addresser. As J. Austin described the speech act as "the total speech act in the total speech situation" [22, p. 2]. In our case, diverse interactions unfolding in the UN Security council encompass sets and sequences of different speech act. However, to have a complete picture of what happens, happened or will happen, we have decided to include a few more tools into our research.

Deception is difficult to identify especially when it is proclaimed by high-ranking speakers who represent time honored institutions like governments. Communication involving deception allows the violation of the rules of conversation, which were formulated by Paul Grice [19]. Universal rules of conversation, also called Gricean maxims, are grouped into 4 categories - the Maxim of quantity, the Maxim of quality, the Maxim of relation and the Maxim of manner [19]. Maxim of relation is least involved in deception in question. Whereas the other three contribute to various degree to mislead the target audience.

In our analysis we employ the universallyoriented 7-level model of an open system previously introduced by O. Kolesnyk [3, p. 45, 74]. In doing so the hierarchy of a sign becomes readily apparent, moving from general information to particular.

Stating the subject of the study. The subject of the Study is the verbal and pragmatic aspects 
of deception of the representatives of the UN Security Council.

Stating the aim of the study and objectives. In this study, we will attempt identifying different verbal and pragmatic aspects of the linguistic expressions of deception on the example of meetings of the UN Security Council. The aim of this paper is to provide interpretations of pragmatic issues of the deception.

To achieve this aim, the following tasks should be solved:

- to identify the purpose of any deception, what is covered up and what is on the surface;

- to characterize language means used in diplomatic speeches to convey false information;

- to show a reaction to the distorted information by their supporters and adversaries in the communicative situation of diplomatic discourse;

- to identify the final result of the deception in the communicative situation of diplomatic discourse.

Problem statement. Currently some problems of DD are the object of close attention of the scholars $[1 ; 2 ; 4 ; 5 ; 6 ; 9 ; 10 ; 12 ; 13 ; 17 ; 21]$, however, there is a lack of special knowledge that would highlight situations when the speakers are economical with the truth in DD of the UN Security Council, which is the relevance of this research.

DD is usually attributed to the institutional type of discourse, which, according to V. Karasik, represents "the speech interaction of representatives of social groups or institutions with each other, with people who realize their status-role capabilities within the framework of established social institutions, the number of which is determined by the needs of society at a particular stage of its development" [3, p. 190-191]. In other words, we are speaking about a trio of the speech act, which J. Austin in his set of lectures "How to do things with words" [16] named as the acts of illocution, locution and perlocution [16, p. 101]. Stated another way, we are dealing with the Act (A) or Locution $[16$, p. 101], when the addresser of the message is forming it in his/her mind, than we have the Act(B) or Illocution [16, p. 101] that leads us to the message itself, in the case of deception that will be a changed on purpose message, and finally appears the $\operatorname{Act}(C)$ or Perlocution [16, p. 101], that shows the end result of the entire speech, which is either the achieved aim of the communication or not. The idea of separating the speech act into components is not a rare thing, exactly the same point of view maintains L. Vikulova as in any other institutional discourse, there are also integral components of communicative-speech activity: sender - message - recipient [1, p. 42].
But to this classical trio it would be reasonable add a modified concept of noise by Claude Shannon $[1$, p. 34], but with the difference in understanding what could be this noise in DD. It is not just some problems in communication because of using gadgets in general, and mobile phones in particular, but as Warren Weaver [1, p. 35] rightly pointed out that noise is actually any interference in communication.

The interference could be in order to conceal some facts and information, or to mislead the addressee. Speaking about the latter, it is vital to have a look on the classification of the addresser and the addressee. In the context of our research, the sender or the addresser is a diplomat, the message is his/her speech, and the recipient or the addressee is another diplomat, or a group of representatives, or it could be people who have an excess to the scripts of the UN Security Council meetings. The scrips of meetings of the UN Security council do not contain 100\% of information, but still they provide the great majority of what was said, to whom it was said, what was the reason of saying that and where it was said.

To consider this issue a little further, it is worth to give a little more information about the addresser and the addressee, who they are or could be. To do this, I will rely on the classification of the addressees by G. Pocheptsov [11, p. 10-17] the addressees are possibly classified as being of 5 types: 1) addressee himself/herself; 2) quasi-addressee (for instance, an unrecognizable listener); 3) addressee-repeater (or mediator); 4) indirect addressee (or listener), 5) co-addressee. We agree with classification, but we would like to adjust the said classification to the specificity of the communicative situation under investigation. The addressee can be viewed as belonging to 2 main groups, which are a) present here and now; b) the whole humanity, who has access to the materials. The first group includes all the diplomats, their teams, guests and in general the whole staff to whom it refers. For example, the group a could be: the president Mr. Bakuramutsa (Rwanda), the members from Argentina is Mr. Cárdenas, from Brazil is Mr. Sardenberg, from China is Mr. Li Zhaoxing and other members [23].There are also representatives who would like to participate in the discussion, but they are not members of the UN Security Council. These could be representatives of Australia, Austria, Canada, Denmark, Indonesia, the Islamic Republic of Iran, Italy, Japan, Poland and Turkey [23]. The second group includes wide audience without any restrictions i.e., everybody who can read the information from the security council meetings somewhere on the Internet, or in different 
magazines, newspapers, etc. That is why, we can definitely speak about different context, which can be either closed, or public [13, p. 49].

Speaking about the addresser, we can speak about the direct and indirect addresser, the latter is also termed as 'retranslator'. In the communicative situation of the induced diplomatic discourse the members of the security council represent their countries and are more likely to be retranslators, informing the agreed point of view of their state. However, the previous classifications are about participants in general, because there is no reference about truthfulness of the exchanged information between the addresser and the addressee. If we take into account the fact, that not all people tell the truth, in this case we can classify them as a) people who tell the truth; b) liars, or as A. Lenets rightly pointed out a homo mentions [7].

It is vital to emphasize the reasons of being economical with the truth. As E. Sheigal noticed, the goal of politicians is the struggle for power [5, p. 35], while the diplomats tend to present their countries on the international stage. But that works only in the official way, because unofficially diplomats tend to gain the control over their opponents and partners [13, p. 49]. At the same time, diplomats support their business, economical and military partners. For example, the USA is traditionally addressed by Russians as an extremely arrogant country. V. Popov mentions that "the world should be the way the United States wants it to be" [10, p. 45]. Actually, such kind of behavior can be typical for representatives of superstates.

The main reasons for the Security Council diplomatic meetings, are thematically grouped as follows: 1) the allocation of public resources, 2) the control of the decision-making process, 3) different sanctions [7]. Consequently, the language of diplomacy can be viewed as the continuation of the politics of a given country and is expected to fulfill several tasks. Firstly, it forms a certain vision of reality among communication partners, i.e. performs the function of orientation. Secondly, the functions of integration and social differentiation, as well as actional function, are commonplace for the said discourse. Thirdly, the function of mobilizing for activity, which manifests itself in various genres ofDD, reflected in the media [13,p. 49]. All of the above functions give a reason to believe that the boundaries of DD have now expanded significantly. In addition to the typical characteristics of DD, it is increasingly revealing features characteristic of other types of discursive practices. Moreover, in one case, this is due to the current situation of social development, in the other - by its deep historical roots [13, p. 51].

At the same time, like any institutional discourse, DD is characterized by the presence of terminology, euphemisms, as well as various clichés. As a part of induced discourse, diplomacy is not locutionary by definition, it is illocutionary with the whole set of long- and short-term tasks imposed on the speaker (retranslator). Speaking about euphemisms, that deal with avoiding the words that do not suit the situation [20], thus the most common couples of euphemisms in DD are the following: instead of saying "the war", quite often in DD we may find "the humanitarian conflict" or just "the conflict"; instead of telling the truth about own "military intervention" we may find "help"; this couple is very similar to the previous one, but with a slightly different shade of meaning, where instead of telling about "the military intervention" it is possible to read about "a freedom fighter" and so on. Moving on to the next tool of misleading the addressee, it is worth to mention the most typical diplomatic terminology. To do this, we will use both the diplomatic dictionary [18] and the records of the UN Security Council's meetings: Embargo [24]; Ambassador [27]; Attaché [25]; Chief of Mission [24]; Communiqué [24]; Resolution [25]; Delegation[26]; Diplomatic corps [26], Protocol [24, 25, 26, 27], etc. These terms are used abundantly, attested in almost every meeting of the Security Council of the UN on the one hand because these words describe the participants of the meeting, on the other hand - there are terminologies that are connected to the subject of discussion. Speaking about clichés, in this list could be all possible greetings and different phrases of politeness, such as: I thank the representative of Rwanda for the kid words he addressed to me [24]; I thank the representative of South Africa for the kind and friendly words he addressed me [25]; I thank the representative of the United States for their kind words [27] and so on.

The linguistic tools mentioned above help to follow or violate the principal rules of communication. This means that being economical with the truth is regarded as violation of maxims, elaborated by Paul Grice. First of all, let us start from a quick review what a maxim is. The Maxime is the rule of communication. There are 4 of them: the Maxime of quantity, the Maxim of quality, the Maxime of relation and the Maxime of manner [19]. The Maxim of quantity is where one tries to be as informative as one possibly can, and gives as much information as is needed, and no more [19]. This Maxime can be easily violated by 
giving either less information that is needed, or giving more information that is needed, usually to confuse the addressee. Or it could be to persuade the addressee to do what the addresser says. Next is the Maxime of quality, where one tries to be truthful, and does not give information that is false or that is not supported by evidence [19]. This Maxime is about the context of giving the truthful information and not a distortion of it. It is very beneficial to the homo mentions (A. Lenets) to violate this Maxime in different situations, i.e. hiding something, justification of his/ her actions, persuading the opponent and so on. The third Maxime is the Maxime of relation, where one tries to be relevant, and says things that are pertinent to the discussion [19]. This one is about following the topic of the discussion, not deviate from the topic and giving only that amount of the information that is needed, neither more, nor less. The last Maxime is the Maxime of manner, when one tries to be as clear, as brief, and as orderly as one can in what one says, and where one avoids obscurity and ambiguity [19].

In case of violation of the said maxims any information could be either not informative, or not truthful, or not relevant, or not clear. But more often it the Maxim of quality, which is violated when the truth is not said, when one doesn't try to be truthful, and gives information that is false or that is not supported by any evidence. This could be done either as on purpose of the facts distortion, or to gain the hidden aims of the addresser. The better the addresser is at conveying information; the more likely the addressee agrees with his/her words.

In other words, Grice's maxims of conversation meant to describe the subconscious process of communication, but in DD the situation is different. The diplomats accurately pick up words, they are thoughtful, careful. It is not characteristic for diplomats to speak emotionally and to show feelings. Also, it is not enough to read or watch the meeting of the UN Security Council. To understand what is going on, it is crucial to know the exophoric context. All deceptive expressions are contextually bound and can be detected only through the real state of things. In this paper we detect the fragments of untrue messages only considering the reply of the other member of the Committee.

Research methodology. The following research has been conducted within the pragmatic direction in discourse analysis that includes theories, which consider general and specific knowledge in the field of DD. We adapted certain results of E. Sheigal to the purposes of our analysis. While analyzing DD, it is important to use the speech act theory(J. Austin), its variations (L. Vikulova) and further classification of the addressee by G. Pochepsov, with an unusual type of the addressee, which is a homo mentions (A. Lenets), i.e. a liar. Also, the pragmatic direction is associated with the study of the sign O. Kolesnyk. Its theoretical and methodological basis is outlined within the paradigm of pragmatic studies. To get the result, the comparison methodology while comparing different levels of deceiving diplomats has been used. Also, with the help of synthesis, the economic and business background of deception has been analyzed.

Novelty. The scientific novelty of the following research is that this is the first of the known studies that addresses the structural and pragmatic properties of modern English-language speeches in the communicative situation of the UN Security Council. New is the focus on the structural and pragmatic specifics of such speeches.

The practical significance. The results of this scientific research will be a contribution to the study of DD and will contribute to a deeper understanding of the correlation between structure, pragmatic content, relevance of selected language units to ensure the success of the diplomatic speech. The results of this paper can be used primarily in the study of courses "Theoretical Grammar" (for instance, while studying "Pragmatics" and "Discourse"), "Fundamentals of Discourse Analysis", in practical classes and lectures for future philologists, translators, journalists, diplomats.

Results of the study. Deceiving as a category of logics existed in the binary opposition of truth vs falsehood. Based on the classical classification of implicatures, any deception consists of what was said and what was meant to be said. In other words, the hidden motive of what was said. Any deception has a certain aim, in other words, it has some communicative intention. Agreeing with A. Morokhovsky, we distinguish two purposes of any communication, which are 1) to inform the addressee and 2) to activate the addressee, to provoke a reactionresponse [9, p. 36]. For example, Mr. Nebenzia's accusation that the Security council has not proven information in the $8633^{\text {th }}$ meeting: On Monday, 16 September, we gave a detailed press conference at which we provided irrefutable data to demonstrate that the allegedly flagrant cases of air strikes by Russia and Syria on civilian infrastructure in Idlib were falsifications. The de-confliction mechanism is being used for misinformation [10]. Therefore, here we may also see the violation of the Maxim of quality, because instead of telling the truth, the Secretary 
council has given not proven information, which could lead to the wrong conclusions. Often the common opinion about diplomat is that deceiving, and deceit is natural for them. This was proved by the quotation of the English diplomat H. Wotton, "A diplomat", he wrote in the diary of a girl, "is an honest man who is sent abroad to deceive in favour of his government" [10]. Wotton is not alone in such judgments. The French writer and satirist, in a book on diplomacy, even called diplomats "chameleons". N. Machiavelli was one of the supporters of the possibility and necessity of deceiving in diplomacy, that even it is permissible for them and that truth harms the interests of the state [10]. But, curiously fact is that Machiavelli at the same time understood that a deception could be detrimental to the diplomat and his actions. Therefore, in his instructions sent to the Florentine ambassador at the court of Charles V, he indicated that the ambassador should strive not to be reputed as a person who thinks one thing and says another. "This shows", he added, "how wrong those who see intrigue as the essence of the diplomatic profession are". Let's see in details typical deceptions in a hierarchical three-dimensional space.

We consider it fair to present the internal categorical aspects of falsity signs which can be variable and constant. Variable signs include three main ones: sender, receiver and presupposition. For instance, a sender could be - Karen Pierce (United Kingdom), Kelly Craft (United States), Juergen Schulz (Germany); a receiver is another diplomat, for example, Anne Gueguen (France), Zhang Jun (China); while presupposition deals with the already known information and both the addresser and the addressee have the same more or less the same age, gender, understanding of the current situation. Permanent signs include violation of intention and sincerity. In other words, when the addresser knows for sure that it is not a piece of truthful information, but he/she still presents as a piece of reliable information. This is also the example of violation of the Maxime of quality, where the disruption of the Maxim shows the intentionally false information. A good example is in the $8609^{\text {th }}$ meeting, where Mr. Polyanskiy blames Mr. Hickey for deceiving: As we have heard today, those terrorists become "innocent babies" and there appear schools and hospitals that have supposedly been bombed by Russia but in fact either did not exist or were not targeted [24]. As we can see, Mr. Polyanskiy demonstrates that Mr. Hickey disregarded the main communication rule, which is telling the truth, no more or less.

However, it is easy to find out other categories of falsity from the position of violation of pragmatic rules: violation of the speaker's intention, i.e. the Maxim of relevance (for instance, there is an example of Syrian's representative Mr. Ja'afarideceiving in the $8609^{\text {th }}$ meeting, and Mr. Alotaibi is trying to prove that his intentions are not these: The representative of Syria mentioned Kuwait while levelling many accusations against Kuwaiti parties and institutions. He usually makes such accusations during his statements, and he has the right to do so. However, it is also our right to reply [24]); violation of significant dimensions of the speech act (for example, in the $8623^{\text {th }}$ meeting Mr.Nebenzia is not sure that all the humanitarian help towards Syria is just to help: First, we should define what goals have been set and which are actually being pursued by its authors. Since the beginning of the discussion, they have said that they have been guided exclusively by humanitarian considerations, are not pursuing hidden objectives of any kind and do not wish to undermine the unity of the Security Council. If that were true, we would support the draft text without hesitation... [25]), i.e. it is also about the violation of the Maxim of quality of what is said; violation of the principle of politeness, i.e. it is about the violation of the Maxim of relation (despite the conflict situation, every diplomat tries to stay polite, for example, Mr. Zhang Jun tries to prove that he is not a liar, but with a pretty good memory: I must point out here that China firmly rejects the groundless accusations made by the representatives of the United Kingdom and the United States against China. China has the right to make an independent decision on how it votes, according to the rights and wrongs of a situation and proceeding from the interests of a certain people. No country has the right to make wilful accusations such as this [25]), etc. [6, p. 123]. It turns out that, to see the whole picture of deceiving it is crucial to know the background information. Formally a typical deceiving or justifying one's actions of not one simple sentence, but it takes a couple of complex sentences, where usually its ending or its beginning is dedicated to the process of deceiving or justifying.

We employ the universal model of an open systems' architecture [5, p. 45, 74] and apply it to the typology of the speakers' pragmatic intentions. The employed model encompasses interdependent levels, that demonstrate causative-consecutive symmetry: while level 7 provides "strategic" and largely axiomatic pragmatic incentives for the micro-pragmatic of level 1, level 6 contains axiological markers that direct the system's verbal behavior and provide its "comfortable" optimal mode at level 2, set up a number of inter-systemic relations 
at level 5 thus stimulating the system's adaptive autotuning ("mental, analytical") mechanisms, level 4 as a fractal copy of the whole model reflects the system's complete structure and its potential ability to extend, expand or transform according to contextually relevant input signals. Let's present this hierarchy on the example of a speech of diplomats of the UN Security Council:

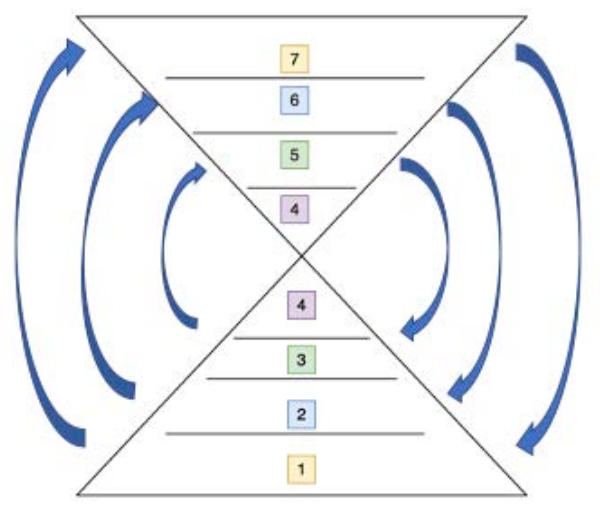

Fig. 1. Hierarchical plane of an open system of the sign

We have considered this model on the example of Ms. Kraft's (America) speech at the 8727th meeting of the UN Security Council [27]:

Level 7 represents meeting of the UN Security Council to discuss the situation in the Middle East; Level 6 is a dissemination of informationabout Russian aviation bombing some Syrian hospitals, homes where children live-Speaking candidly, it is a marvel to me that our Russian colleagues can speak of ceasefires and political solutions in this Chamber with a straight face when their own warplanes have struck hospitals and the homes of children; Level 5 is an implicit incentive for various factions to decide not to support Russia in its terrorist attacks on civilians-The Council cannot allow Syria, Russia and Iran to continue pursuing the subjugation of Syrian civilians, as failure to end the Al-Assad regime's assault through a United Nations-brokered ceasefire risks the lives of millions of internally displaced persons, most of them women and children; Level 4 is a mobilization of the delegation of representatives of this country around the Syrian problem, the Russians can no longer be trusted, they falsify the facts; Level 3 is modeling of further peaceful communication without the Astana group - It was not clear before but it is certainly no longer appropriate to trust the Astana group to end the violence; Level 2 is where Ms. Kraft tries to embarrass Russian delegates - it is a marvel to me that our Russian colleagues can speak of ceasefires and political solutions in this Chamber with a straight face; Level 1 is a cessation of such shameful behavior on the part of Russians colleagues.

a. At the same time, Mr. Nebenzia (Russia) does not stay aside and accuses a colleague from America, Ms. Kraft, of deceiving. Let's see in detail how this happens: Level 7 coincides completely with the speech of the previous diplomat where a meeting of the UN Security Council to discuss the situation in the Middle East; Level 6 is a dissemination of information about American support for terrorist actions the terrorists they cherish are in danger; Level 5 is the opposite implicit incentive for different factions to decide now not to support Russia, but America is in cooperation with terrorists - Some are playing the card of civilian suffering and long-term truce every time the terrorists they cherish are in danger; Level 4 is a mobilization of a delegation of representatives of this country around the Syrian problem, where it is no longer possible to trust not the Russians, but American supporters of terrorism the terrorists they cherish; Level 3 is a projective modeling of further cooperation without any performance - Some are playing the card of civilian suffering; Level 2 is an attempt to embarrass Ms. Kraft for a performance with terrorists - Some are playing the card of civilian suffering and long-term truce every time the terrorists they cherish are in dangeach otherer; Level 1 is stopping the game of one actor.

Thus, to identify a liar it is necessary to see the whole picture of the speech act of lie in general, and in details at the same time. Because only after doing that, it is possible to understand not only the reason of deceiving, but the background of it, the difference of perception some information and producing it to the addressee. In the example above, we may see challenging relations between Russia and America. Thus, taking into account the situation in Syria, which was discussed above, we may add other conflicts between these two superstates, which are: 1) the interference in the presidential elections (2016, 2020); 2) the annexation of Crimea; 3) Russia's support for Syria's Bashar al-Assad in the civil war. The most negotiated issue is the third one. However, nobody knows for sure how long this situation will last, but till now U.S.-Russian relations remain frosty.

Therefore, all these diplomats do not argue or lie randomly, because they just want to do it. If we look more attentively, we will see the pragmatic background of their behavior. First of all, not some particular diplomats that represent their countries take part in conflict, but those countries that are members of the following 5 military alliances such as: The Collective Security Treaty Organization (CSTO), The Shanghai Cooperation Organization 
(SCO), The North Atlantic Treaty Organization (NATO), The European Union (EU), The League of Arab States. Let's show their relationships in a diagram (figure 2 ).

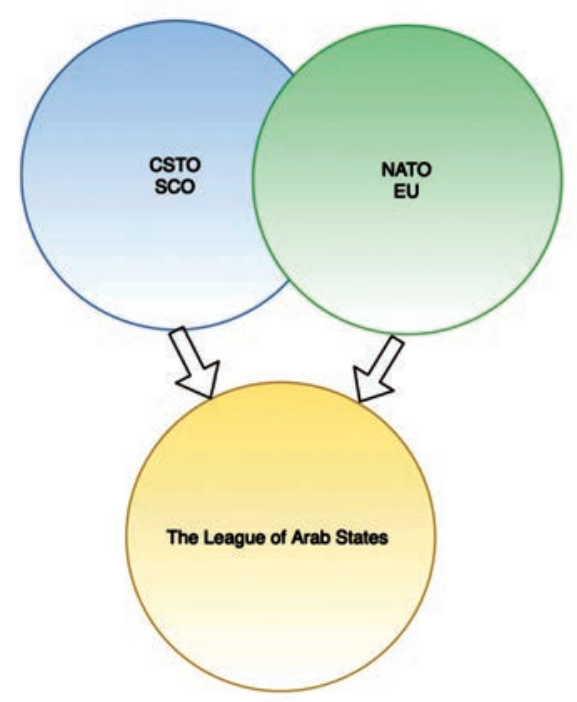

Fig. 2. The connection between alliances

This diagram illustrates the relation between three main groups of alliances, where 1) CSTO with SCO and 2) NATO and EU are two groups that are experience relationship (money and their power in the market); while 3) The League of Arab States is the place where the previous two alliances experience their relationship(like we see in Syria). In other words, we see the relationship between such countries as the USA, China, Russia, Germany, Belgium, Britain, France, Estonia, that represent the first two circles and Syria, Tunis in the last circle. The majority of military and economical conflicts are about countries that are in the League of Arab
States. This article has shown just the beginning of our further research where we will show in details the connection between diplomats, military alliances, who is deceiving and why.

Conclusions. Thus, deception in induced diplomatic discourse manifests several peculiarities:

a) in DD deception can be said in clichés, euphemistic words and expressions

b) there is a conflict between the sender and the recipient: the sender distorts the reality, whereas the recipient is fully aware of the sender's communicative efforts to conceal the truth.

Deception in DD is not a personal matter, a diplomat operates as a retranslator and transmits the point of view of the institution/country they represent.

It is possible to consider deception in DD as collective product of alliance of countries or political blocks.

Language units that constitute the premises of the analyzed discourse construals reveal the following semiotic properties:

- three-dimensional space of the sign in the semantic level (its connection with the subject), pragmatic (with the person) and syntactic (with other signs);

- communicative, i.e. the function of communication between communicators (diplomats);

- information that is reflected in the submission of new or the refutation of some previous information;

- its material form, the way a person (a diplomat can absorb it);

- a sign can endure only in its appropriate area of existence, for example just among diplomats and during their meetings.

The prospects for further study include the detailed analyzes of the hierarchy of pragmatic attitudes.

\section{References:}

1. Викулова Л. Г., Шарунов А. И. Основы теории коммуникации: практикум. Москва : Восток-Запад, $2008.316 \mathrm{c}$.

2. Гольдин В. Е. Имена речевых событий, поступков и жанры русской речи. Саратов : Жанры речи, 1997. 212c.

3. Карасик В. И. О категориях дискурса. Языковая личность: социолингвистические и эмотивные aсnекты : сборник научных трудов. Волгоград - Саратов : Перемена, 1998. С. 185-197.

4. Клаус Г. Сила слова. Гносеологический и прагматический анализ языка / пер. с нем. Москва : Прогресс, 1967.216с.

5. Колесник О. С. Міфологічний простір крізь призму мови та культури : монографія. Чернігів : РВВ ЧНПУ імені Т.Г. Шевченка, 2011. 312 с.

6. Ленец А. В. Коммуникативный феномен лжи: лингвистический и семиотический аспекты: на материале немецкого языка: дисс. ... докт. фил. наук : 10.02.19. Ростов-на-Дону, 2010. 382 с.

7. Ленец А. В. Перспективы научного направления «лингвистика лжи» в России и Германии. URL: $\quad$ https://cyberleninka.ru/article/n/perspektivy-nauchnogo-napravleniya-lingvistika-lzhi-v-rossiii-germanii-1/viewer (дата звернення: 20.01.2021). 
8. Лингвистический энциклопедический словарь. URL: http:/tapemark.narod.ru/les/ (дата звернення: 15.01.2021).

9. Мороховский А. Н. Стилистика английского языка. Киев : Выща шк., 1991. 270 с.

10. Попов В. И. Современная дипломатия. Теория и практика. URL: http://bwbooks.net/index.php?id1=4 \&category=politika\&author=popov-vi\&book=2000\&page=148 (дата звернення: 11.12.2020).

11. Почепцов Г. Г. О коммуникативной типологии адресата: избранные труды по лингвистике. Харьков : ХНУ имени В. Н. Каразина, 2009. С. 450-455.

12. Соловьев Ю.Я. Воспоминания дипломата 1893-1922. URL: http://az.lib.ru/s/solowxew_j_j/text_1932_ vospominane_diplomata.shtml (дата звернення : 02.12.2020)

13. Терентий Л. М. Дипломатический дискурс как особая форма политической коммуникации. URL: https://cyberleninka.ru/article/n/diplomaticheskiy-diskurs-kak-osobaya-forma-politicheskoy-kommunikatsii (дата звернення: 23.12.2020).

14. Успешность коммуникации: постулаты П. Грайса и максимы Дж.Лича. Речевой этикет и вежливость. Языковые средства выражения вежливого отношения к собеседнику. Понятие фатической коммуникации. URL: http://linguistics-konspect.org/?content=9263 (дата звернення: 09.02.2021).

15. Шейгал Е. И. Семиотика политического дискурса. URL: https://cyberleninka.ru/article/n/2001-02-010sheygal-e-i-semiotika-politicheskogo-diskursa-in-t-yazykoznaniya-ran-volgogr-gos-ped-un-t-volgogradperemena-2000-368-s-bibliogr-s (дата звернення: 14.11.2020).

16. Austin J. L. How to do things with words. URL: https://pure.mpg.de/rest/items/item_2271128_6/ component/file_2271430/content (дата звернення: 02.02.2021).

17. Denton R. E. Jr. Woodward GC Political Communication in America. New York : Praeger, 1985. 328 p.

18. Glossary of diplomatic terms. URL: http://www.ediplomat.com/nd/glossary.htm (дата звернення: 10.02.2021).

19. Grice's Maxims. URL: https://www.sas.upenn.edu/ haroldfs/dravling/grice.html (дата звернення: 11.02.2021).

20. Kis Mirjana Euphemisms and military terminology. URL: http://www.ffzg.unizg.hr/hieronymus/wpcontent/ uploads/2014/09/Hieronymus_1_2014_Kis.pdf (дата звернення: 01.11.2020).

21. Naer V. Pragmatics of the text and its components. M. : Pragmatics and stylistics, 1985. P. 9-18.

22. Sbisà M.Locution, illocution, perlocution. URL: https://www.researchgate.net/publication/261180528 Locution_illocution_perlocution_In_Pragmatics_of_Speech_Actions_Ed_by_M_Sbisa_and_K_Turner_25-75_ Mouton_de Gruyter_2013 $9783 \overline{1} 10 \overline{2} 14383$ (дата звернення: 09.02.2021).

23. $3 \overline{4} 84^{\text {th }}$ meeting. URL $:$ https://undocs.org/en/S/PV.3483 (дата звернення: 09.01.2021).

24. $8609^{\text {th }}$ meeting. URL: https://undocs.org/en/S/PV.8609 (дата звернення: 11.11.2020).

25. $8623^{\text {rd }}$ meeting. URL: https://undocs.org/en/S/PV.8623 (дата звернення: 13.11.2020).

26. $8633^{\text {rd }}$ meeting. URL: https://undocs.org/en/S/PV.8633 (дата звернення: 13.11.2020).

27. $8727^{\text {th }}$ meeting. URL: https://undocs.org/en/S/PV.8727 (дата звернення: 15.11.2020).

\section{ГОЛЬЦеВа М. І. ПРАГМАТИКА ОМАНИ В РАДІ БЕЗПЕКИ ООН: \\ ІЄРАРХІЯ ПРАГМАТИЧНИХ ПІДХОДІВ}

У статті розглянуто мовні прояви введення в оману в комунікативній ситуачї інституиійного дипломатичного дискурсу (засідання РБ ООН) з прагматичного погляду. Оскільки дипломати представляють свої країни на світовій арені, іноді вони можуть подавати інформацію в найбільш вигідному для них світлі. Інакше кажучи, вони вводять в оману своїх опонентів. Для грунтовного проведення аналізу нами також долучено до аналізу тривимірну структуру знаку. Виявлено сім рівнів знаку, щио продемонстрували структуру введення в оману на дипломатичних засіданнях, починаючи від причини зібрання засідання, закінчуючи тим, який саме кінщевий результат досягнуто. Зокрема, на приклад продемонстровано, як безпосередньо проявляються зазначена вище семирівнева природа знаку.

Установлений тривимірний знаковий простір продемонстрував семантичний, синтаксичний і прагматичний рівні. Визначено, що мета введення в оману й спотворення інформаиї̈ полягають у приховуванні або навмисному спотворенні фактів. Оманлива поведінка адресанта-ретранслятора є продовженням політики держави, яку він представляє. У ситуаиії засідань РБ ООН уведення в оману не видається одноосібним комунікативним актом, а підпорядковується інтересам політичних блоків, виступаючи засобом для взаємних претензій політичних союзів.

Крім того, ми з'ясували прагматичне підтрунтя введення в оману, яке бере свій початок далеко за межами стін РБ ООН. У результаті проведеного дослідження ми визначили три групи економічних, політичних і військових інтересів, представники яких належать до таких військово-економічних альянсів: 1) ОДКБ та ШОС, 2) НАТО й СС, 3) Ліга арабських держав. Перші дві групи альянсів є головними противникали, які, як правило, частіше за все конфліктують. Остання група, як правило, є плацдармом для вирішення суперечок між попередніми двома.

Ключові слова: мовленнєвий жанр, уведення в оману, прагматичні установки, знак, прагматика. 